DOI https://doi.org/10.36059/978-9934-588-42-6/1-18

\title{
STRUCTURAL-AND-FUNCTIONAL MUSIC AND LANGUAGE SKILLS CHARACTERISTICS IN THE UNDERSTANDING OF ART
}

\section{Beilin M. V., Soina I. Yu.}

\section{INTRODUCTION}

Enrichment, improving and mobility of knowledge are the priorities of education today. The knowledge together with abilities and skills is an indicator to determine the level of the individual's competence. Society needs a competent individual who is capable to think creatively and to operate acquired knowledge, including arts. These needs and requirements led to the search for new understanding of concept "art knowledge". The influence of art on such well-established category as knowledge has such feature that appears in its information and emotional-sensual constituent. Updating and acquiring new knowledge of art closely related to the cognitive processes of understanding, perception and thought. Significant role in these processes play experience, consciousness, intellect and man's worldview. In this context the formation of artistic knowledge, which has some differences due to age and influence of art on young people, is important. Therefore, all these aspects contribute to knowledge potential of mankind, the achievement of knowledge, its understanding and possibilities to use it in appropriate situations of life. In art education there are a number of unresolved issues relating to the formation of individual artistic knowledge in integrated music classes, their structure and method of formation. Knowledge can not be constant, though consisting of wellestablished elements, which are its basis. New information is superimposed on the constant knowledge, becomes a component of information plurality of already known knowledge, comes to them in a close relationship and absorbed.

\section{From the "cognition - knowledge" to "understanding - knowledge"}

One of the most important processes of the present civilization is the transition to post-industrial stage of development of society. It is characterized by growth of information and dynamic development of the 
processes of a "diving" a man into an open, global, changing information environment. The main resources of the society, therefore, are knowledge and information. They perceived a man using a consistent mental activity. Post-industrial society can be considered technotronic, that is so that in the cultural, psychological, social, economic and artistic connections and relationships shaped by technology and electronics. Technotronic revolution affects not only the nature and features vivid perception of reality, but also creates a renewed large-scale, global vision of the world as a whole, and in particular in the sphere of art. In such circumstances, there is a problem urgent formation of a competent individual who thinks creatively and is able to comprehend the complex world. An important part of competence is knowledge, the formation of which the art industry has a certain feature. The processes of consciousness influence on it, and without them it is impossible the perception and the adoption of knowledge, thinking, artistic cognition and emotional intelligence. At different times the interpretation of the concept was different: contrasting concepts of "thought" and "knowledge" (Antiquity), antagonism and interaction of the terms "faith" and "knowledge" (Middle Ages), the category of "secular knowledge" (Renaissance), a priori and a posteriori knowledge (New time). According to F. Becon, the main reason of the slowing of the thought processes is weak use of reason and minimal addressing to art, emphasizing that art itself contributes to a better and more rapid assimilation of knowledge ${ }^{1}$. Knowledge, experience and influence of art are the main categories without which new knowledge cannot be acquired. Knowledge is a process and result values inherent the art; phenomenon of vivid reflection of reality. "Knowledge" is defined as a special form of spiritual assimilation of the results of cognition, the process of reflection of reality. That knowledge helps people navigate the surrounding reality, which basically comprises theoretical and experimental data on various phenomena of the world. Representatives of neo-kantianism (including H. Rickert) shifted the emphasis from the relationship between the concepts "cognition knowledge" to "understanding - knowledge" for the first time putting on the centre of discussion the understanding and knowledge problem. Subjects of

${ }^{1}$ Бэкон Ф. Сочинения : в 2 т. Академия наук СССР. Институт философии. Москва: Мысль, 1971. Т. 1. 296 с. (Серия «Философское наследие», Т. 42). C. 201 . 
understanding were information and knowledge about the world or the world of a particular subject ${ }^{2}$.

An attempt to dissolve the concept of "understanding" and "knowledge" by nature of origin was made by V.V. Rozanov. In his treatise "On Understanding", the philosopher states that knowledge comes down to simple registration of facts, self-evident things, events and phenomena, without raising questions about the reasons that cause them to life. He defines knowledge as something fragmentary, disorderly, that does not combine different phenomena into one whole, inextricably linked and firmly entrenched by internal causal connection. Understanding is considered integral, which brings together individual phenomena through close links ${ }^{3}$.

I. Ilyinsky in his work "The Twentieth Century: The Crisis of Understanding" (2002) identified the causes of the crisis of understanding at the present stage, showed the consequences that accompany the escape from knowledge and understanding in the context of "information waste". The author formulated a proposal to overcome the crisis - to create an "educational revolution". This revolution is necessary not only to improve the forms and methods of knowledge transfer and new educational technologies, but also to rethink the educational mission. Traditionally, training is reduced to mastering a certain amount of knowledge. This tendency must be reversed through the teaching of understanding, without which perceived information cannot become a full-fledged knowledge ${ }^{4}$. Knowledge should be regarded as the unity of rational and sensual, individual and social, objective and subjective, finite and infinite, general and singular, inevitably linked to the means of definition through which it takes the form of its sole existence, localized in space and time. Information that is absorbed by a person is transformed into knowledge, becomes "his own" only on the basis of knowledge and experience. In an information society, knowledge and information interact and conduce one's selfrealization. The knowledge of the individual consists of peculiar "cell", among which there are empty. They are filled with information that, through

2 Тихомірова Ф.А. Інтеграція та диференціація: єдиний механізм розвитку наукового знання. Ученые записки Таврического национального университета им. В.И. Вернадского. Серия: Философия. Культурология. Политология. Социология. 2010. Т. 23 (62). № 1. С. 54-60.

3 Розанов В.В. О понимании. Опыт исследования природы, границ и внутреннего строения науки как цельного знания. Санкт-Петербург: Наука, 1994. 540 c. C. 12.

4 Ильинский И.М. Образование и кризис понимания. Информационный гуманитарный портал «Знание. Понимание. Умение». 2006. № 2. С. 5-10. 
the thought process, integrates data from different sciences about a particular subject or phenomenon. Initially, this data is housed in different "cells" that we assume may not be related to each other, housed in the subject's shortterm or long-term memory, and coloured by some human experience. However, having identified some links between the eclectically placed information data of these cells, they fill the "empty cells" with new information data. Only if they are "remelted" through the lens of their own experience, perceived by the subject and become "his own" - these data become new integrated knowledge.

It can be assumed that the formation of artistic knowledge occurs through the application of the principle of coincidence of information from different types of arts or disciplines. Assuming that artistic knowledge consists of "cells" containing information from the subjects of the artistic-and-aesthetic cycle, and not only, it is by means of thought operations (artistic thinking actions) that a "coincidence" will take place, which will fill an empty cell of artistic knowledge, creating thus a new formation. The information plurality of the concept "knowledge" can be delineated by the system of blocks and the thesaurus category. In this context, the knowledge thesaurus of the individual can be compared to a flash drive, which contains a lot of information. This information should be structured and placed in certain information blocks that are formed around the central semantic conceptkernel. Thus, the thesaurus of the individual becomes a kind of basic on which the entire array of scientific material is superimposed. The breadth of a thesaurus is directly proportional to the knowledge and experience of a person, obtained from the conflicting information material, from which the thesaurus picture of the world is constructed. It can be considered as a criterion that allows to determine the degree of development of the whole content and structure of the thesaurus as a structured idea of the generalized idea of that part of world culture that the subject can master. This term and its dynamics have been studied and continue to be studied in connection with the supersaturation of human with information in the conditions of "information explosion" . Attention should be paid to the phenomenon of thesaurus fractality when acquiring knowledge. "Fractal" is regarded in scientific sources as an irregular, self-like figure, small parts of which in arbitrary magnification are similar to itself. The term "fractal" was introduced into scientific vocabulary in 1975 by B. Mandelbrot. It is

5 Луков В.А. Фрактальность тезаурусов/ Информационный гуманитарный портал «Знание. Понимание. Умение». 2008. № 9. URL: http://www.zpujournal.ru/e-zpu/2008/9/Lukov_fractality/ 
advisable to consider the fractality of artistic knowledge. Fractality manifests itself in this way: at first one cell of knowledge in any kind of art or discipline (music, fine arts, literature, etc.) appears. It can manifest itself through artistic concepts, phenomena, terms. Her initial task is simply to survive, to "stand" and "to dig in" (in its field of art). In this capacity, this knowledge cell acquires the ability to "survive", fill, and influence independently other cells that are still chaotic and empty. Through the interaction with similar ones, the empty cells are filled, eventually become dominant and build a block system, components of which will be drawn to the central semantic concepts-nuclei (fractals). Their multiplicity will be the informational content of an artistic thesaurus. Through thinking operations, the structured artistic information of an art thesaurus becomes "one's own" and is transformed into artistic knowledge, thus creating an artistic picture of the individual's knowledge.

Artistic knowledge cannot be constant, though it consists of permanent knowledge nuclei. These elements are the basis of the artistic knowledge that the individual has acquired previously. Over time, this artistic knowledge is overlaid with new artistic information that comes into close relationship with it and assimilates it ${ }^{6}$. As a result, new artistic knowledge and a new artistic picture of the world are formed, as well as a change in the understanding of the information that has been learned previously. Thus, artistic knowledge is constantly changing, characterized by flexibility and fluidity. Thesaurus is a kind of complete systematic baggage of information (knowledge) and aims in a particular field of life, which allows you to navigate in it. It says that in a thesaurus knowledge forms a certain fusion and exists according to the laws of the value-normative system and the concept of "alien - one's own" forms the core of the thesaurus. From the other perspective, the relation between thesaurus-information and thesaurus-knowledge is considered by Z. Bimenova. She emphasizes that the most successful translation of the term "thesaurus" is to understand it as "the world of knowledge and interests", "the world of knowledge and interests of the child - the thesaurus of the child", "the world of knowledge and interests of the artist - the thesaurus of the artist" ${ }^{\text {" }}$. Studying the concept of thesaurus, M. Gitis draws

6 Soina I.Yu., Semenova Yu.A., Goncharov G.N., Petrusenko N.Yu., Kambur N.A., Chervona S.Ph. Poetic Understanding as the Initial Input of Beingin-the-world. Amazonia Investiga. Vol. 8. Num. 20. Mayo-Junio 2019. pp. 261-263.

7 Гендина Н.И. Информационно-поисковые тезаурусы: основные виды и области применения. Научные и технические библиотеки. Москва: Государственная публичная научно-техническая библиотека России, 2008. C. 5-14. 
his attention to the special approach in which frames are proposed as the thesaurus components ${ }^{8}$. They are used as a way of grouping information. The general idea of the frame method of representation of knowledge was formulated by M. Minsky: in his system each frame has its structure, between the elements of which there are close links. Thanks to these links, the frame is able to speed up the processing of information coming to the subject in the process of perception. Therefore, frames play an important role in the formation of knowledge. However, M. Gitis notes that frames can include words spoken language (i.e. thesaurus) and others (visual images, sequence of actions, sound images). They provide the fastest understanding of a work, developing the thinking of man. Thinking through sound frames should mean the different types of information stored in and used by a person. Frame thinking in music is able to quickly organize in the thesaurus listening information, which is stored in such a way that it is possible to almost instantly recognize a particular genre, author's style, compositional scheme, etc. ${ }^{9}$. The frame is one of the important components of thinking, and information is transformed into knowledge.

In art education, the category of "knowledge" through the tangential concept of "thesaurus" is considered by L. Masol. Seeing the factor of integration of knowledge in art thesaurus, she defines it as a set of concepts in a certain field of knowledge, repository, human experience: "The experience of the individual should be understood as a set of concepts, images, operations, semantic links, as well as a dictionary of these basic concepts. In pedagogy, a thesaurus plays the role of an informational basis of learning. Increasing the same amount of information, assimilation of new knowledge must be accompanied by the complication of the educational thesaurus as a kind of landmark compass in an endless sea of artistic concepts and terms" ${ }^{\prime \prime}$.

The unique quality of the music is occurring in a special way of giving an idea of reality and the world around it. V. Lektorsky believes that the process of consciousness formation has at its core three types of activities that are interconnected: external practical activity, the process of cognition

8 Гиттис М.И. О закономерностях восприятия комического эффекта, передаваемого средствами киномузыки. Известия российского гос. пед. университета им. А. И. Гериеена. 2010. № 124. С. 261.

9 Гиттис М.И. О закономерностях восприятия комического эффекта, передаваемого средствами киномузыки. Известия российского гос. пед. университета им. А. И. Гериена. 2010. № 124. С. 256-263. - С. 261.

${ }^{10}$ Масол Л.М. Теоретико-методологічні засади інтегрованого навчання мистецтва. URL: http://refdb.ru/look/3377390-pall.html. 
and communication" ${ }^{11}$."Knowledge itself, not information, should be the subject of particular attention when studying the information space, in general, and communication processes in particular. Knowledge is informational in nature and is characterized by the following properties: productivity, structure, latency. Defined properties allow not to reduce personal knowledge to hidden (latent) and social knowledge to the subject" ${ }^{, 12}$.

The sign-and-symbolic way of acquiring knowledge by an individual should be viewed in a musical-linguistic context, that is, attention should be paid to the language of music. Therefore, the main category is becoming musical and linguistic knowledge, the specification of ideas about this category and the need to consider this problem from the standpoint of internal and external reality. Musical and linguistic knowledge is one of the components of the category of "knowledge" in the broader context, namely in philosophy, semiotics, psychology, psycholinguistics and musicology. Such comprehensive consideration of the main category will allow to regrasp the phenomenon of musical and linguistic knowledge and to determine the orientations of the organization of cognitive activity of the individual. The range of attraction includes both knowledge of language (knowledge of "linguistic facts", "linguistic material" of music) and knowledge of the language of music (normative ideas about the structural and functional features of musical and linguistic phenomena). The system of relations (links) between knowledge: these are "knowledge-experiences", which are formed by an infinite multiplicity of "casts" of specific linguistic facts of musical reality and generalizations that have arisen on their basis, as well as knowledge of language ("meta-linguistic knowledge") that summarizes the most general, normative characteristics of linguistic elements and transforms them into facts of theory. "Existing knowledge" is transformed into the category of "personal knowledge", while the objective characteristics of the first are transformed into subjective abilities of the person. Therefore, when studying the question of the category of "knowledge", the assessment of "alien - one's own" is used. In this context, a natural question arises about the transition of knowledge of the "external" to the "knowledge internal", i.e. the transition from "alien to one's own".

11 Лекторский В.А. Субъект, объект, познание. Москва: Наука, 1980. 359 с. C. 177.

${ }^{12}$ Каптерев А.И. Использование профессионально-интеллектуального потенциала как условие модернизации экономики РФ. Pucк: pecypcbl, информация, снабжение, конкуренция. 2013. № 4. С. 302. 
Externally imposed artistic information overlaps and qualitatively interacts with artistic knowledge previously acquired by the individual, resulting in a new understanding of prior artistic knowledge in the light of new artistic information. If one thinks that art is syncretic at its core, two opposite tendencies are to be revealed: differentiation and integration.

\section{Content and structure of artistic knowledge: information and axiological components}

In philosophy, the concept of "structure" is considered as a set of connections between parts of the object. At the same time, it is not only about the constant interconnection between the parts of the whole, but also about the way of organizing its elements in the system, its "basic, initial structure, which forms the spatio-temporal configuration or form of this whole. The concept of "knowledge structure" means a stable and orderly relationship between knowledge of a certain type and the classifier of knowledge that is inherently variable, any formation of knowledge is always associated with the inclusion of new knowledge in the structure of knowledge that has already become actualized. Thus, the structure of knowledge is enriched and supplemented. Knowledge has a commonly defined classification hierarchical structure, each element of which is directly or indirectly related to the elements of other hierarchical structures". It examines knowledge of musical art in two planes: in the first plane, it identifies knowledge that helps to form a generalized, holistic view of musical art, that is, the nature of music, its function and meaning in human daily life, aesthetic norms and criteria for musical culture, and the other is attributed to the knowledge that aids musical observation (patterns of development of art of music, genre-style variety, features of intonation language of art, structured form and means of artistic and imaginative expression). The leading idea in structuring is the division of knowledge into the key knowledge of the language of music, "reflecting the most common phenomena of musical art and associated with the laws of the development of musical art, features of the musical language, the specifics of the musicalhistorical process (style era, genre, individual author, musical work) and specified (knowledge of musical literacy; individual specific elements of musical language (sound, tempo, metro-rhythm, dynamics, mood, timbre, agogic), musical-historical in relation to the history of the development of music art, biographic data about composers, performers, and the history of creation of works". The informational component of artistic knowledge refers to a block of information in the field of art that goes from alien to one's own in the individual's consciousness. This path, in turn, is 
accompanied by the individual's ability to assimilate information using different thinking actions, namely: analysis, synthesis, comparison, generalization, classification, systematization of artistic information. The axiological component of artistic knowledge relates to the emotional-value sphere of the individual. It implies the ability to emotionally respond to the works of art and forms a valuable attitude to material models of $\operatorname{art}^{13}$. Artistic information has its own specificity, which manifests itself in the peculiarities of sources of artistic information (painting, literary, musical, or artistic work). Such perceptual information is transmitted through colour, word, timbre and sound to the subject of perception. Information about various artistic is processed by means of thinking operations (artistic and thinking actions). In this case, it will be perceived, understood and assimilated by the individual and transformed into "knowledge". Therefore, the concept of "assimilation" should be understood as the process of assimilation of artistic information that an individual receives from various sources. Thus, this process is characterized as the interaction, interpenetration and reciprocal complementation of knowledge that has been previously perceived and that information that is new to the subject.

Let us analyze the art thesaurus as a factor of integration and the information basis of teaching and artistic thinking. The term "thesaurus" is not artistic, but borrowed from the field of computer science and linguistics. That is why the interpretation of the term "thesaurus" in the reference literature are different: "dictionary", "treasure", "treasury", "world". With the development of the intellectual skills of the individual, the thesaurus grows, increases in volume and the educational thesaurus complicates like a kind of compass - guide of the individual in the space of artistic concepts. The content of an art thesaurus implies a set of terminological knowledge and a certain amount of concepts, aiming to capture a universal conceptual and art categorical apparatus; to improve the ability to handle specific terms directly in discussing works of art, musical constructions and creative works of artists; to know and to understand musical culture, especially the arrangements of folk and classical music, the specificity of traditional and modern arrangements of folk music, displaying peculiarities of ethnic motives in classical and contemporary music; to be able to perform songs, to create elementary accompaniment to them; to compare original musical works and their arrangements, to apply knowledge and skills of arranging

${ }^{13}$ Shpitsa R. A phenomenon of artistic knowledge in the context of modern musical and pedagogical education. Intellectual Archive. 2015. Vol. 4. No 6. Toronto: Shiny World Corp. 178-189 pp. 
folk music in their own performing arts. At the same time, it is important to understand the peculiarities of modern musical phenomena (jazz, pop, rock, chanson, song), the differences between rock opera and musical from classical music and theatre genres, expressive means of electronic music; to distinguish and to perform vocal works of modern genres; to express emotional and value attitude to works of modern musical art; to create your own music compositions using computer technologies; to apply knowledge of contemporary music trends in their own creative activity.

The second element of the information component of artistic knowledge is artistic acts of thinking (operations) - the basis without which the process of assimilation of artistic knowledge will not take place. It is necessary to distinguish the following operations of artistic thinking among others: abstraction, reasoning, correlation, elaboration, connection between images, the process of transformation, reintegration, perseveration and animation, as well as consideration of the presence or absence of elements of beautiful and grand, tragic or comic, genre and style features. According to these operations the result of thinking presented through the conclusion: a comparison of the world phenomena with a real standard; generalization, occurrence of judgments and formulation of concepts. The result of artistic thinking that can be observed in the field of art: emotional experience, artistic evaluation (criticism, interpretation), the emergence of a new artistic image.

Let's consider mental actions in more detail. Analysis in this context is the separation of terms, works of art, biographical information about artists and artistic phenomena in the mind, the separation of certain parts, elements, features, properties, and aspects in them. Artistic expressiveness analyzes the artwork; with the help of this mental operation - the creativity of the artist, or the artistic phenomenon as a certain style in art. Generalization is "the ordering of information, the continuation and deepening of the synthesizing activity of the brain through the language of art" (words, sounds of music, paints, gestures, etc.), which has a generalizing function and rests on the character nature of the essential properties of art displayed by it. Generalization of certain essential features of objects and phenomena of art makes it possible to group objects according to certain characteristics or means. Among the most important means of artistic expression are: word, epithet, metaphor, hyperbole - in literature; colour, perspective, texture, composition, chiaroscuro in fine arts; sound, dynamics, rhythm, timbre, intonation - in musical art; movement and plastic - in choreography.

However, every artwork that is mastered by the individual requires the fullest possible use of artistic thinking and understanding, which consists not 
only in the perception of the work by means of expressiveness, but also by the artist of the work, and epoch, and stylistic features, and a number of well-known creative figures that the artwork associates with. Understanding of an artwork, first of all, should be seen as a process that involves the active processing of artistic information, proposing one's own hypotheses, points of view, questions to the text, agreement or disagreement with the author or the way of the work. This is what becomes the basis for artistic generalization of certain phenomena. Appropriate mental operations find connections between the types of arts and the works of art that are perceived. The complexity of artistic generalization is the ordering of a large amount of artistic theoretical and practical information. This generalization requires the appropriate preparedness of the listener. For example: a favourite means of creating artistic images is to apply the effects of contrast of light, shadows and their nuances; depicted figures emerge from the depths of a dark background with extraordinary expressiveness; thanks to them the author achieves the realism of still life paintings, portraits and multi-figure compositions in which the viewer's attention is drawn to the plot of the painting - these are the main features of the manner of painting of the artist Michelangelo Merisi da Caravaggio; orbs, capillaries, temples in honour of the gods, harps - Antiquity. The complexity of generalization is that an individual must not only possess artistic information, be able to find links between works of art and types of art, but process artistic information in order to absorb new knowledge based on the synthesis of information that was already acquired.

The axiological component of artistic knowledge involves the emotional perception and value of artistic information. Formation of artistic knowledge of an individual cannot be done formally and unemotionally. Emotion (fr. emotion - "worry", "excitement") is a certain reaction to an artwork (an irritant) to a colour, sound, word; it is such a state of worrying or excitement that is marked by strong feelings. The same artwork can evoke different emotions in an individual, depending on his experience, level of consciousness, emotional response to a piece of music, temperament and artistic imagination. In our opinion, the emotion that arises in an individual on an artwork (positive or negative) cannot leave him indifferent to art. It becomes a kind of indicator of interest in the assimilation of information. This feature distinguishes the formation of an individual's artistic knowledge in integrated music lessons, from assuming, those acquired in the study of mathematics or computer science. The works of art are exactly directed to the emotions of a person, aimed at "capturing" him, forcing him to sympathize and empathize, that is, to show empathy. Considering the 
relationship of emotions with the needs, motives and vital meanings of a person, one should emphasize the depth of the concepts of "emotional activity" and "emotional intelligence". They characterize a person's ability to recognize their own emotions, possess them, motivate them and understand other people's emotions. The emotionality during mastering music knowledge and knowledge about music is undeniable. The concept of "emotions" in psychology is regarded as the activity of evaluating information about the external and internal world, which enters the brain of the individual. Emotions have a pronounced specificity, which is manifested in reaction to events that are coloured by personal meaning. If this event is rated as positive, then the emotion prompts action to support it. Accordingly, in order to generate interest in music and art, it is necessary to select very carefully those phenomena of musical art that can provoke a strong emotional response. One of the extremes of such a reaction is excessively strong emotional excitement (affect). It can occur against a background of low levels of emotion control. A special emotional atmosphere contributes to the effective formation of interest in music, and in accordance with it the acquisition of new knowledge. The organization of diverse activities is based not only on aesthetic emotional experiences, but also on other types of emotions. Among these emotions are: communicative, practical, gnostic, hedonistic and romantic. Communicative emotions allow the individual to share their experiences, find them feedback. Practical emotions come about through activity or its change in the course of work, success and enthusiasm for the products of their work. These emotions primarily influence on the aesthetic importance of the process of activity. The importance of focusing on gnostic emotions associated with the need for cognitive activity and the penetration of the phenomenon should be emphasized. Gnostic emotions can not only contribute to the formation of interest in music, but also become the basis of interest. However, the formation of interest in the individual will not be filled without hedonistic and romantic emotions, since the need for such emotions arises in connection with the formation of their own "I" and the expectation of something unusual, light miracle, excitement of feeling transformed by the perception of the surrounding reality.

Let us dwell in detail on two elements of the axiological component: emotional response to works of art and value attitude to works of art. Emotional reaction should be understood as such emotional processes (states) that arise in an individual when perceiving or performing a particular artwork, it is a kind of emotional response of the soul to artistic phenomena, or a particular piece of music. Considering the emotional response of an individual to a piece of music, we trace the relationship of his 
feelings/needs with his emotional reaction, which arises during the perception of works of art and influences the formation of artistic knowledge.

The emotions are understood in the psychology as the main adaptive mechanism of psychological processes. Thus, K. Izard believes that the fundamental principle of human behaviour is that emotions energize and organize perception, thinking and action ${ }^{14}$. However, emotion is the precondition for cognitive activity, the more cognition is associated with the core "I", the more emotions are involved. "Emotions" are the specific forms of interaction of the individual with the outside world, which are directed to its cognition and understanding of his place in it through himself. This specificity is manifested in the essential qualities of the positive and negative poles of emotion (polarity of pleasant and unpleasant), the opposite of tension and discharge, excitement and depression.

Music and artistic emotions that arise in the cerebral cortex affect the human intellect. They are the basis for the aesthetic development of the individual. As a rule, emotions of the mind are formed not immediately, but undergo a long stage of formation together with the development of musical perception. The formation of musical perception goes through four stages: the stage of sensorimotor training, the stage of perceptual actions, the stage of formation of aesthetic models and the heuristic (creative) stage. In the first stage of sensorimotor training there are sensations and primary cognitive processes of the relation between the stimulus and the object; there are simple emotional reactions: a complex of revival, eye movement, a smile. The stage of perceptual actions is based on the occurrence of active actions aimed at the examination of the subject. At this stage the perception of the individual, which is based on perceptual sensations and the constant signs of music (rhythmic, timbre) are memorized, is noticeably improved. This increases the emotional response to specific pieces of music. Substantial perception of musical works arises at the fourth stage of the formation of aesthetic models. At this stage, mental operations of collation, comparison, and evaluation of perceived music are activated. Small works or individual pieces of music are generalized, forming in the representation of the recipient certain models: genre (march, symphony, opera, aria), frets (major - minor), forms of musical work (simple-complex, two-, three-part, reprise). At the same time, the listener has a stable emotional attitude to certain pieces of music (captures the drama of certain pieces of music by P. Tchaikovsky, relaxes the harmony of certain works by V. Mozart and F. Chopin). So, we

\footnotetext{
${ }^{14}$ Izard C.E. The psychology of emotions. N.-Y.: Plenum Press. 1991. 452 p.
} 
can talk about appreciation of the music of a particular artwork. Depending on the individual's auditory experience, intonations can be fixed in the mind (sexton intonation is associated with romance, and quartone intonation is associated with march). That is, perception becomes more and more conscious. Perception and its stages directly related to emotional reactions and a thesaurus of the person. In the process of perception of musical works an individual forms the thesaurus - a dictionary of traces of his past impressions, which can come to life under the influence of a musical work that is entrenched in human memory.

Thus, the influence of musical works on the listener, the development of his thinking, human perception of certain works, the emotional reactions that arise in this case, play an important role, as the perception of music develops mechanisms of thinking: analysis, comparison, synthesis, generalization, it improves the imaginative language of the individual, which promotes the development of his cognitive interests and extends thesaurus. The perception of music is impossible without the awareness and understanding of what is perceived. "One should never refuse to assert an intellectual beginning in musical perception, because listening to music we not only feel or experience certain states, we respond emotionally to musical works, but also differentiate perceived material, conduct selection, evaluate and, therefore, think" ${ }^{\prime 15}$. This, in turn, confirms the truth of the sentiment of the philosopher R. Descartes: "Cogito ergo sum" (I think, therefore I exist).

Along with considering the emotional response to works of art, one should analyze the value attitude to artworks, since it is the second element of the emotional-and-value component of artistic knowledge. The category of "value" should be understood as the positive or negative significance of environmental objects for a person, class, group, society as a whole, which is determined not by their properties, but by their involvement into the human life, interests and needs, social relations. Formation of precisely inadequate past values restrains the person, distorts his course of life, significantly reduces or even make impossible the self-realization. The social "I" of a person, which harmoniously incorporates in the subjective form a set of socially significant values, is created in the process of developing its moral and spiritual consciousness and self-awareness. Consciousness provides the development of attitude to certain moral norms, their personal meaning and personal properties, and self-awareness provides their emotional-and-value assessment, that is, leads to their transformation into relevant personal

15 Асафьев Б.В. Избранные статьи о музыкальном просвещении и образовании. Л.: Музыка, 1973. 144 с. С. 58. 
values. Leveling of values in today's society leads to a global spiritual crisis, where people are transformed into "spiritual skeletons". Today, there is a change in the value orientations of modern youth: from generally humanistic to pragmatic, mercantile. This contributes to the formation of inadequate transient values among young people, resulting in the loss of value to the works of high art, the vector of which is shifted to low-grade "template" art. Values have objective foundations in human nature, since the search for stable foundations of personal being is inherent in human. This concept is used in philosophy and sociology to designate objects, phenomena, their properties, as well as abstract ideas that embody social ideals and, thanks to this, serve as the standard of what is necessary for which a person aspires.

The value orientations of the personality are dynamic and contradictory; they are based both on the pursuit of high ideals and on daily needs and interests. Value orientations are values that are realized by the person, which serve the purpose in life and the main means of achieving them. Values and value orientations reflect the fundamental interests of the individual, determine the strategic orientation of its activities. They are manifested as the vital position of the individual, his worldview, moral principles. They are a sign of the maturity of the individual, integrity, reliability, loyalty to certain ideals, active life position. Values are formed in the process of life people, they rise above daily practice and actively influence the formation of goals, motives and choice of activity. Thus, the concept of "value orientations" should be considered as a system of attitudes of the individual to certain values of material and spiritual culture of society. However, scientists emphasize that this factor, along with human experience, influences the experience of the individual and, first of all, his emotional state. It is necessary to take into account the significant changes in the value orientations that in modern society can occur during different stages of human life. Such changes directly affect the structure of value orientations, where three levels can conditionally be distinguished: competency-based; emotional and behavioural.

\section{CONCLUSIONS}

The artistic knowledge of the individual is considered as a combination of information from various types of art, which are the result of the perception and understanding of artistic phenomena and is reproduced in the human mind in the form of concepts, judgments and emotional-and-value relationships and serves as the basis for the formation of an artistic picture of the world. 
Due to the disclosure of the essence of the basic concept, the structural components of artistic knowledge are theoretically substantiated, each of which consists of two elements: information component (artistic thesaurus and artistic-and-thinking actions) and axiological (emotional reaction to works of art and value). It has been ascertained that the success of forming the first component depends on the ability to transform artistic information and terminology; to comprehend and assimilate it with the aid of artistic thinking. Thus, it becomes the property of the individual, which is used when discussing artistic phenomena, styles and works of art, and enriches the artistic thesaurus of the individual. The second component of artistic knowledge involves the ability to emotional response to works of art and the formation of a value attitude to them. Such modern tendencies of art education development as integration and cultural orientation, support for practical activity, partial unloading of the individual are revealed. Organizational-and-methodical model of artistic knowledge formation of the individual consisted of organic interrelationship: tasks, scientific approaches, principles, objective and subjective factors, technologies, forms and methods (search, reflection, game, with the use of information technologies and a group of projective methods). The method of the artistic knowledge forming of the individual includes three consecutive stages of work: information, artistic and creative.

\section{SUMMARY}

The concept of "knowledge" is considered as the result of cognitive activity, a set of ideas, a generalized experience of cognitive and transformative interaction with a object-related phenomenon of the world, as perceived, comprehended, stored in memory and reproduced at the right moment information for solving theoretical and applied problems. It is ascertained that the knowledge of the individual is not constant, but this knowledge forms a certain dynamic formation, which consists of components - agile informational variables - and are characterized by integrativeness, dependence on the process of cognition, personal activity and experience of the individual. It is noted that artistic knowledge is an ever-changing activity-and-psychological entity and can exist only as "unity in diversity"; as a complete set of information from different types of art, which is the result of a specially organized artistic and cognitive activity to comprehend and summarize the content and internal polystructural interrelations of artistic phenomena. It is proved that new artistic information becomes knowledge only if it is conceived and adopted through assimilation. The basic directions of consideration of artistic knowledge are identified, 
among which we distinguish: cultural, cognitive, thesaurus, comprehensive, integrative-and-personal and systemic. It is ascertained that artistic knowledge is viewed in close connection with understanding; art knowledge, which is characterized by high emotionality, perception, mental operations, consciousness and intellect. Based on the thesaurus concept, it is determined that artistic knowledge cannot be constant, it is constantly changing. New artistic information is assimilated with previously acquired knowledge through mental operations, resulting in the emergence of new artistic knowledge. The mechanism of its formation is defined, namely, artistic information transforms into knowledge only if it has passed the path: "perception-understanding-comprehension-assimilation".

\section{REFERENCES}

1. Асафьев Б.В. Избранные статьи о музыкальном просвещении и образовании. Ленинград : Музыка, 1973. 144 с.

2. Бэкон Ф. Сочинения : в 2 т. ; Академия наук СССР. Институт философии. Москва : Мысль, 1971. Т. 1.296 с.

3. Гендина Н.И. Информационно-поисковые тезаурусы: основные виды и области применения. Научные и технические библиотеки. Москва : Государственная публичная научно-техническая библиотека России, 2008. С. 5-14.

4. Гиттис М.И. О закономерностях восприятия комического эффекта, передаваемого средствами киномузыки. Известия российского гос. пед. университета им. А.И. Гериена. 2010. № 124. C. 256-263.

5. Ильинский И.М. Образование и кризис понимания. Информационный гуманитарный портал «Знание. Понимание. Умение». 2006. № 2. С. 5-10.

6. Каптерев А.И. Использование профессионально-интеллектуального потенциала как условие модернизации экономики РФ. Риск: ресурсы, информация, снабжение, конкуренциия. 2013. № 4. C. 299-303.

7. Комплексные исследования: тезаурусный анализ мировой культуры. Информащионный гуманитарный портал «Знание. Понимание. Умение». 2008. № 9. URL: http://www.zpu-journal.ru/ e-zpu/2008/9/

8. Лекторский В.А. Субъект, объект, познание. Москва : Наука, 1980. $359 \mathrm{c}$. 
9. Луков В.А. Фрактальность тезаурусов. Информационный гуманитарный портал «Знание. Понимание. Умение». 2008. № 9. URL: http://www.zpu-journal.ru/e-zpu/2008/9/Lukov_fractality/

10. Масол Л.М. Теоретико-методологічні засади інтегрованого навчання мистецтва. URL: http://refdb.ru/look/3377390-pall.html

11. Розанов В.В. О понимании. Опыт исследования природы, границ и внутреннего строения науки как цельного знания. СанктПетербург : Наука, 1994. 540 с.

12. Poetic Understanding as the Initial Input of Being-in-the-world / I.Yu. Soina at al. Amazonia Investiga. 2019. Vol. 8. Num. 20. Mayo-Junio. P. 261-263.

13. Тихомірова Ф.А. Інтеграція та диференціація: єдиний механізм розвитку наукового знання. Ученые записки Таврического национального университета им. В.И. Вернадского. Серия: Философия. Культурология. Политология. Сочиология. 2010. Т. 23 (62). № 1. C. 54-60.

14. Izard C.E. The psychology of emotions. New York : Plenum Press, 1991. 452 p. DOI: $10.1007 / 978-1-4899-0615-1$

15. Shpitsa R. A phenomenon of artistic knowledge in the context of modern musical and pedagogical education. Intellectual Archive. Toronto : Shiny World Corp., 2015. Vol. 4. № 6. P. 178-189. DOI: 10.15587/25194984.2019.170645

\section{Information about authors:}

Beilin M. V.,

Dr. habil. in Philosophical Sciences, Professor, Professor at the Department of Humanities

Kharkiv State Academy of Physical Culture 99, Klochkivska Str., Kharkiv, 61058, Ukraine

Soina I. Yu.,

Candidate of Philological Sciences, Associate Professor, Associate Professor at the Department of Ukrainian and Foreign Languages Kharkiv State Academy of Physical Culture 99, Klochkivska Str., Kharkiv, 61058, Ukraine 